University of Wollongong

Research Online

Faculty of Business - Papers (Archive)

Faculty of Business and Law

$1-1-2016$

Conventional accounting in determining an enterprise's wealth: sign or referent - a theoretical discourse for augmentation

Sudhir C. Lodh

University of Wollongong, slodh@uow.edu.au

Follow this and additional works at: https://ro.uow.edu.au/buspapers

Part of the Business Commons

Research Online is the open access institutional repository for the University of Wollongong. For further information contact the UOW Library: research-pubs@uow.edu.au 


\title{
Conventional accounting in determining an enterprise's wealth: sign or referent - a theoretical discourse for augmentation
}

\begin{abstract}
Purpose: This paper is an attempt to assess the duality check of wealth determination through corporate reporting using the currently accepted accounting equation and/or conventional accounting. That is, the theory of interest here is to explicate as to whether prevailing accounting equation is adequate to capture all plausible realities in determining absolute economic (or otherwise) wealth of an entity.

Design/methodology/approach: In enhancing a theory of interest and sensitising our argument on conventional accounting, there is a necessity to use methodical discretions; which ultimately 'inform and reflect the implicit epistemology and metaphysics' (Ravenscroft and Williams 2009) of our discipline of accounting. We have used extant (critical) accounting literature to put forward a theoretical discourse on the context of determining an enterprise's wealth using two metaphors - sign to referent (Baudrillard 1983, 1994a, 1994b), in particular, when conventional accounting and/or Balance Sheet approach is considered.

Method/data: An extensive literature both theoretical and practicing issues on accounting are collated from differing journal articles, books (mostly interdisciplinary in nature), websites, accounting standards and conceptual frameworks issued by professional accounting bodies.

Findings: An augmented accounting framework is suggested in order to indicate the gaps that may arise in the prevalent accounting equation. This is inherent in the system when compared through different layers - sign to referent. That is, in a dynamic environment it is suggested that there is a need for augmentation for better representation of economic and social reality through corporate reporting.

Research contributions: We argue that this augmented framework will enhance our understanding within the domain of fair value accounting, confidence accounting, provision of integrated value creating elements and discharging social responsibility, in relation to the missing elements and the nature of corporate reporting. We conclude from our discussion that prevalent accounting standards such as IFRSs (or otherwise) are considered to be signs and have epistemic objectivity. That is, the determination of wealth (in accounting) based on the current signs is, as always, objective. Whilst any different layer is considered other than the sign layer and if a comparison is made pairwise, there will always be differentials/gaps in determining absolute wealth for an entity using signs that exist at any time and space and, therefore, there is a need for augmented thinking. Therefore, we see the determination of wealth for an enterprise in accounting not only is considered to be subjective, it is socially constructed and constructing; and there needs to be an ongoing discourse which should have dialectical force for change.
\end{abstract}

Originality and value: Not only is the augmented framework applicable for the measurement perspective for corporate financial (or otherwise) reporting; it is also applicable for ideological debate on accountability and sustainability of how we see the improvement of a greater humanity and justice across the world economies through corporate reporting.

\section{Disciplines \\ Business}

\section{Publication Details}

Lodh, S. C. (2016). Conventional accounting in determining an enterprise's wealth: sign or referent - a theoretical discourse for augmentation. APIRA 2016: 8th Asia-Pacific Interdisciplinary Research in Accounting Conference (pp. 1-31).

This conference paper is available at Research Online: https://ro.uow.edu.au/buspapers/915 


\title{
Conventional accounting in determining an enterprise's wealth: Sign or referent - a theoretical discourse for augmentation Sudhir C Lodh University of Wollongong, Australia
}

\begin{abstract}
Purpose: This paper is an attempt to assess the duality check of wealth determination through corporate reporting using the currently accepted accounting equation and/or conventional accounting. That is, the theory of interest here is to explicate as to whether prevailing accounting equation is adequate to capture all plausible realities in determining absolute economic (or otherwise) wealth of an entity.

Design/methodology/approach: In enhancing a theory of interest and sensitising our argument on conventional accounting, there is a necessity to use methodical discretions; which ultimately 'inform and reflect the implicit epistemology and metaphysics' (Ravenscroft and Williams 2009) of our discipline of accounting. We have used extant (critical) accounting literature to put forward a theoretical discourse on the context of determining an enterprise's wealth using two metaphors - sign to referent (Baudrillard 1983, 1994a, 1994b), in particular, when conventional accounting and/or Balance Sheet approach is considered.
\end{abstract}

Method/data: An extensive literature both theoretical and practicing issues on accounting are collated from differing journal articles, books (mostly interdisciplinary in nature), websites, accounting standards issued by professional accounting bodies.

Findings: An augmented accounting framework is suggested in order to indicate the gaps that may arise in the prevalent accounting equation. This is inherent in the system when compared through different layers - sign to referent. That is, in a dynamic environment it is suggested that there is a need for augmentation for better representation of economic and social reality through corporate reporting.

Research contributions: We argue that this augmented framework will enhance our understanding within the domain of fair value accounting, confidence accounting, provision of integrated value creating elements and discharging social responsibility, in relation to the missing elements and the nature of corporate reporting. We conclude from our discussion that prevalent accounting standards such as IFRSs and GAAP (or otherwise) are considered to be signs and have epistemic objectivity. That is, the determination of wealth (in accounting) based on the current signs is, as always, objective. Whilst any different layer is considered other than the sign layer and if a comparison is made pairwise, there will always be differentials/gaps in determining absolute wealth for an entity using signs that exist at any time and space and, therefore, there is a need for augmented thinking. Therefore, we see the determination of wealth for an enterprise in accounting not only is considered to be subjective, it is socially constructed and constructing; and there needs to be an ongoing discourse which should have dialectical force for change.

Originality and value: Not only is the augmented framework applicable for the measurement perspective for corporate financial (or otherwise) reporting; it is also applicable for ideological debate on accountability and sustainability of how we see the improvement of a greater humanity and justice across the world economies through corporate reporting.

Key words: The Accounting Equation, Augmented Accounting Framework, Confidence Accounting, Fair Value, Corporate Reporting, Integrated Reporting

Paper type: Research article 


\section{Introduction}

The currently accepted Accounting Equation [Assets - Liabilities = Wealth] is a derivation of the double-entry bookkeeping system (cf., Pacioli 1494) first expressed in its algebraic form by Charles Sprague in the late $19^{\text {th }}$ century (cf., Sprague 1880). This duality check applying such an equation is to explain or to account for changes in the net balance in wealth accounts based on the underlying causes that are responsible for the change (Ijiri 1989). Over the last century several authors have elaborated on the double entry bookkeeping for financial reporting and/or preparation of financial statements, for example, Chatfield (1974), Littleton (1933, 1968), Patton and Littleton (1940), Sweeny 1936, Littleton and Yamey (1956), Hatfield (1930) and Ijiri, (1986, 1989). ${ }^{1}$ It (duality check) essentially ties in with the comparison between wealth and income using a collection of flows that have occurred in past events which are considered to be transparent, transaction based and objectively measured. Financial reporting including the preparation of financial statements, is primarily an outcome of such an application, its purpose, according to Statement of Accounting Concepts SAC 2 (in Australia - the objective of general purpose financial reporting ) being to provide users with information about a reporting entity which is useful for making and evaluating decisions about the allocation of scarce resources. (Financial Reporting Handbook 2009, p.3) When, for example, the general purpose financial reporting (GPFR) can meet this objective it will ultimately be indicative of discharging the accountability to those users by the management and the governing bodies of the reporting entity. (Financial Reporting Handbook 2009, p.3) But, in recent years several authors have cast doubt on whether the conventional accounting framework (expressed formally in various Conceptual Frameworks) is able to display the absolute economic (and social) reality and accountability in totality in a dynamic environment through such conventional financial reporting (viz, Miller and Napier 1993, MacIntosh et al 2000 and Baker 2006). There are many reasons for such a view. For example, Miller and Napier (1993) argue that "accounting changes in both content and form over time; it is neither solid nor immutable". (p.631) MacIntosh et al (2000) argue that: “(m)any accounting signs no longer refer to real objects and events and accounting no longer functions according to the logic of transparent

\footnotetext{
${ }^{1}$ The purpose of this paper is not to deal with the historical development of single-entry or doubleentry bookkeeping system however.
} 
representation, stewardship or information economics". ${ }^{2}$ (p.13) Baker (2006) argues that "the form of an accounting display has no relationship with the economic 'reality' which the display purportedly represents" (p.678)

In a Presidential Scholar address at the American Accounting Association (AAA) meeting August 2008, Palmrose (2009) explored the fundamental question of whether accounting is at a crossroads of its own conception. She argues that:

We may need to draw on paradigms other than the traditional ones, like economics and psychology from social sciences... In centuries past, the guiding lights of double-entry accounting were people well connected to the larger scientific communities of their times. So perhaps, once again, science can inspire, as we take up the challenge of reconsidering the foundations of accounting in the $21^{\text {st }}$ century. (p282)

Palmrose (1989) further emphasises that "the (US) Conceptual Framework is not particularly helpful for students (of accounting) when considering how to understand GAAP and (whether) they apply to answer real-world questions" (p289). She argues that it was necessary to find such answers and face the reality of financial reporting which will ultimately reflect a fair representation and usable for decision usefulness. For her 'we need to understand the basics' including the accounting equation. She further claims that "we have lost touch with our accounting foundations somewhere along the way" (p 292). It is the complexity (measurement gaps) and invisibility (as far as the accountability gap is concerned) which have been major themes threading through the truths of inconvenient accounting. Clarke and Dean (2007) also argue that "financial disclosure in accord with conventional accounting generally fails to disclose a company's wealth and progress and that the newly heralded IFRSs (International Financial Reporting Standards) will do little to remedy that” (p12).

These contradictions give rise to a question as to whether or not the application of the conventional accounting using 'sign' reality ${ }^{3}$ only will lead to fully capturing the dynamic nature of accounting realities and their underlying consequences. In order to exemplify the dynamic nature of accounting and its duality check to assess the underlying reality in measuring wealth for decision usefulness using fair (or otherwise) values at two layers (sign and referent) we argue that there is a necessity to

2 In order to advance this thesis they used Jean Baudrillard's (1983, 1994a, 1994b) theoretic on postmodernity.

${ }^{3}$ Here we refer sign reality as to the applied accounting standards (e.g., IFRS, GAAP, etc.) that are in existence in any context. 
develop an augmented framework that can exemplify the missing elements in the conventional accounting equation. ${ }^{4}$

To us, the theory of interest here is to explicate as to whether prevailing accounting equation is adequate to capture all plausible realities in determining absolute economic (or otherwise) wealth of an entity. In enhancing such a theory of interest, we have applied a few methodical discretions to link with the above theory of interest. That is, to us, methodical discretions are the use of rhetoric and/or 'language sets' (Laughlin 1995) as devices for inscribing, framing and staging our narratives to put forward a critical discourse on such a pivotal aspect of the determination of absolute wealth of an entity. We have used two extant 'language sets'/metaphors (i.e., sign and referent) as the methodical discretions to develop an augmented framework in order to show the missing portions of the accounting equation that should be considered in determining economic reality (wealth) and discharging accountability at these comparative layers in a dynamic environment. In particular, we have considered two of these language sets - sign and referent - from Baudrillard (1983; 1994a, 1994b) which have already been used in the accounting literature (cf., MacIntosh et al, 2000 and Mattessich 2003). The uses of these two metaphors, we believe, will enable us to open up the debate at least at some level of appreciation as to what makes the gaps as far as the missing portions of the accounting equation are concerned and to develop an augmented framework. In particular, the use of these two metaphors - sign and referent - is to create arbitrary positions to show a comparison of wealth and accountability determinations for these layers and their plausible pervading interdependencies that can shed light on the historical roots of the development of accounting as well as the prevailing gaps/differentials that are inherent in the conventional accounting equation in representing economic reality and discharging accountability at different "layers", (Mattessich 1987, 1989, 1995, 2003).

\footnotetext{
${ }^{4}$ We are not attempting to provide the determination of the missing elements at all micro levels; rather we make an attempt to elaborate plausible missing elements at an aggregate level in the accepted accounting equation or in conventional accounting in determining the absolute economic (or otherwise) wealth through a duality check, if needed.

5 Mattessich (2003, p446)) reiterated his earlier work (Mattessich 1995) in "The Onion Model of Reality" (OMR) and argued that "The OMR belongs to the same family as the ontological theories of Hartmann, Campbell, and Lorenz, but with some differences. It regards the layers of reality as dependent on and inclusive of each other, like those of an onion. It also conceives of these different levels from a multidimensional perspective that includes time and other dimensions, instead of seeing the layers in a linear and one dimensional way." Our analogies of the usage of sign and referent is somewhat similar to Mattessich's analogy of the OMR; but the question remains as to how big or small
} 
Ravenscroft and Williams (2009) argue that:

Root metaphors are particularly significant to any discipline, because such metaphors delimit the implicit assumptions of what is real, what is significant, how things relate, what can be known, and how it can be known. The root metaphor thus informs and reflects both the implicit epistemology and metaphysics of a discipline. ( $p$ 772)

For example, Ravenscroft and Williams (2009) further argue that the adoption of an information metaphor has thrust on accountants the responsibility of making an imaginary (alleged) world which can reflect economic wealth better, or, at least, can be useful to the users of financial reports. We believe the use of the above metaphors will be helpful in making sense of the inequality in the extant accounting equation (of course, at the aggregate level) if ALORE (Asset, Liability, Owners equity, Revenue ${ }^{6}$ and Expense) items ${ }^{7}$ are measurable at various 'layers' (Mattessich 1995, 2003) of comparison; provided the 'realer' (Bougen and Young 2012) can make all items of the ALORE hand 'real' at the referent level in the preparation of financial statements. To reiterate, it is obvious in our view, differentials between the 'left' and 'right' side of the accounting wealth determination, as always, can arise due to either inadequate measurement tools or expectation differences in the deliberations of accountabilities in a given context and space-time. However, instead of considering all the ALORE hand items individually here we would like to show how our concept of an augmented framework can be applicable to various facets of accountings' representations including fair value accounting, confidence accounting and integrated reporting.

Laux and Leuz (2009) argue that "the fair value debate is far from over and much remains to be done' ( $\mathrm{p}$ 833). There have been many attempts by the IASB to converge conceptual framework projects with the FASB in order to improve completeness and consistency (Whittington 2008). According to Whittington (2008, p142), the most obvious gap is in respect of the development of guidance on measurement. But, we will argue that, in addition to the measurement gap, there are obvious gaps in relation to the discharge of accountability to users of financial reporting and the greater community. Therefore, in considering both measurement and accountability gaps, an example of the debate on fair value determination will be

the onion will be. Is it knowable at a given time and space? Also, what would be the ways one could determine the layers of realities using certain epistemic positions?

${ }^{6} \mathrm{We}$ used the term 'Revenue' to refer to 'Income' (e.g., revenue and gains). This use is only to form the word ALORE which is easy to recite and can be used as a root metaphor in our accounting discipline.

${ }^{7}$ Here in after we refer ALORE items as 'the items in ALORE hand'. 
undertaken at our selected two layers: sign and referent. It should however be mentioned that it is not claimed that this paper attempts to identify all detailed elements of the plausible gaps of measurement and accountability discharge of financial reporting that may arise. Rather, the intention is to indicate the missing portions, albeit, at an aggregate level, of 'the accounting equation' and/or conventional accounting, and thus, the urgency is the development of an augmented framework. To make this framework workable in practice, we argue that there is a need for advanced systems to be developed to identify the missing elements (ie, gaps) depending on the layers and contexts under consideration. ${ }^{8}$

The organisation of the rest of the paper is as follows. First, the theory of interest and methodical discretions in relation to the use of two metaphors or language sets: sign and referent - is presented. Second, the debate on the duality check using conventional accounting in assessing economic reality is explored. Third, an explanation is provided for how these metaphors in representing the economic realities along with accountability discharge and their comparative differences between layers are applicable individually. In so doing, an augmented framework is proposed to include the missing portions (in a dynamic environment) to the accounting equation, of course, at the aggregate level. Fourth, a note is provided as to how comparative fair values between layers under consideration can give rise to differentials using our augmented framework. Fifth, convincing arguments are forwarded with a few examples ${ }^{9}$ as have been raised by academics and professionals which can be considered useful to enhance understanding about our augmented framework, at least, at the level of pedagogy, for corporate reporting. A conclusion is drawn in the final section.

\section{Theory of interest and methodical discretions}

As has been argued earlier, the theory of interest here is to explicate as to whether prevailing accounting equation is adequate to capture all plausible realities in determining absolute economic (or otherwise) wealth of an entity. In enhancing such

\footnotetext{
${ }^{8}$ It should be noted that, in a way, we see in recent times some practitioners are thinking along this line. For example, CISI (Chartered Institute for Securities \& Investment), Long Finance, and ACCA (Association of Chartered Certified Accountants) in United Kingdom have jointly published a paper and put forward a proposal what they labelled as "confidence accounting" (see CISI, Long Finance and ACCA 2012). As well, we also see the value of Integrated Reporting (IR) framework as has been launched by the International Integrated reporting Council (IIRC) (see IIRC 2013).

${ }^{9} \mathrm{We}$ are not claiming that these are exhaustive examples. There is a need for elaborative research to identify the outcry with authentic examples from both academic and professional literature.
} 
a theory of interest, we believe, there is a necessity to use methodical discretions to relate with the (contextual) theory of interest; which ultimately 'inform and reflect the implicit epistemology and metaphysics' (Ravenscroft and Williams 2009, p772) of our discipline of accounting. These methodical discretions are then to be used as rhetoric and/or 'language sets' (Laughlin 1995). That is, these rhetoric or metaphors are to be used in developing the theory of interest as devices for inscribing, framing and staging such a complex elaboration of narratives that has long wended historical roots in accounting.

Our pivotal concern here as to whether it is plausible to determine an absolute wealth of an entity in a dynamic environment that we are facing in today's contemporary world through the use of conventional accounting. But, from the literature, we see that there has been a plethora of ongoing debates on the underlying realities (economic or otherwise) that the accounting discipline can represent (cf., MacIntosh et al 2000, Mattessich 2003, Mouck 2004, Baker 2006, Bougen and Young 2012). This reflexivity on the representation of underlying realities in accounting is not just serendipity however. In our view this thematic/fundamental issue has a considerable history. As far as the measurement literature is concerned its origins can be traced back to the 1960s (cf., Mattessich 1964, Chambers 1965, Sterling 1970a, Vickrey 1970, Ijiri 1972, Beaver and Demski 1979, Beaver 1991, Willett 1987, 1988, Salvary 1989 and Gibbins and Willet 1997). Irrespective of the approaches undertaken or normatively put forward whether it is neoclassical or otherwise, so far, there is no agreed applied theory on measurement which could trace the referent in order to trace the absolute wealth of an enterprise. That is, for example, all the prescriptive theories such as current purchasing power accounting (CPPA) (cf., Mathews 1965, Rosenfield 1975), current cost accounting (CCA) (cf., Edwards and Bell 1961), continuously contemporaneous accounting (CoCoA) (cf., Chembers 1966) and deprival value accounting (DVA) (Baxter 1975) have its respective stances in relation to tracing the absolute wealth of an entity.

Since we used two metaphors such as sign and referent from the work of Baudrillard (1983, 1994a, 1994b) and the accounting literature (cf., MacIntosh et al 2000, Mattessich 2003); therefore, there is a need for an elaboration of these methodical discretions. Mattessich (2003) used these terms to exemplify the thematic issues of MacIntosh et al (2000), of course, with some reservations. We are using these 
metaphors here to create arbitrary positions only in order to show the missing portion(s) of the accounting equation and to develop an augmented framework.

MacIntosh et al (2000, p 14) argue that:

Baudrillard uses his ideas about simulacrum, implosion and hypereality to propose a radical description of postmodern society. Briefly, simulacrum is a sign, image, model, pretence, or shadowy likeness of something else. Implosion occurs when the boundary between two or more entities, concepts, or realms, melts dissolves or collapses inward and their differences disappear. Hyperreality refers to the current condition of postmodernity where simulacra are no longer associated with any real referent and where signs, images, and models circulate, detached from any material objects or romantic ideals.

MacIntosh et al (2000, p 16) further argue that:

For many of today's pressing accounting issues, there is no underlying reality to which accounting signs refer... The idea of accounting as a sign, a faithful representation of physical and social realities in space-time, is pervasive. Indeed, the assertion that historical cost accounting keeps track of resources (a physical reality) under the control of entities (a social reality) is an axiom in virtually every text following Paton and Littleton's (1940) influential work (Ijiri 1980).

In a broader sense, following Jean Baudrillard's work, according to MacIntosh et al (2000), the signs can be created by observing the impressions or following the existing rules and principles. In this sense, the current Conceptual Framework(s), regulations and standards including EDs (Exposure Drafts), IFRS (International Financial Reporting Standards), SFAS (Statement of Financial Accounting Standards) and Integrated Reporting (IR) framework can be considered as part of the creation of signs for the preparation of GPFRs. On the other hand, the term referent is indicative of tracing actual resources or obligations. Jean Baudrillard used the terms sign-toreferent in a cultural (social) context; which may have different theoretical underpinnings. But, for our purposes, we argue that these language sets (or metaphors) do give us a skeleton (Laughlin 1995) structure to view the gaps and indicate the missing elements to the current accounting equation. MacIntosh et al (2000) argue that, in Sumerian "urn-accounting”, signs might refer to real physical resources. They went on to argue that this premise might have even persisted in the most sophisticated financial accounting practices that prevail in today's practice because, according to McIntosh et al (2000), accounting now-a-days deals with more complex transactions and uses money as a numeraire. This is a reason why they cast doubt on financial and/or corporate reporting and questioned whether "every dollar on a balance sheet (statement of financial position) can be traced to an actual resource or 
obligation of an accounting entity, just as every token in an urn or impression on an urn could be traced in ancient times" ( $\mathrm{p}$ 16). They further argue that "the same signfunction seems to underlie historical cost accounting practices, which struggle to sustain the belief that contemporary accounting represents reality in much the same way as it did for the ancient Sumerians". (p 16)

Mattessich (2003), in a footnote, states that, according to Baudrillard, signs can be regarded as being an imitation of a real event (p 460 - footnote 22). However, we are reiterating the use of the metaphor of sign as a function of creating an impression in measuring or identifying issues of accountability in financial and/or corporate reporting through following the existing rules and standards (e.g., IFRS, GAAP) that are provided by today's professional bodies (e.g., IASB, FASB, etc.); which can be seen as an "epistemic objectivity" as proposed by Mouck (2004) and Baker (2006) who used Searle's (1995) work. In order to pursue our arguments further we need to elaborate the term 'simulacra'; which is considered by several accounting researchers (Bougen and Young 2012, MacIntosh et al 2000).

Baudrillard's theoretic on 'The Orders of Simulacra' first appears in English with 'The Precession of Simulacra' in the volume Simulations (Baudrillard 1983). Indeed, as Butler (1999) argues it was an attempt to criticise Michel Focault's famous The Order of Things (Foucault 1977). Butler (1999) argues that Foucault's attempt was to write a history of representation, Baudrillard attempted to write a history of simulation that will in a sense be critical of the realist pretensions of Foucault's effort (p35). In 'The Orders of Simulacra', Baudrillard (1983) identifies three different orders or stages of simulation: the counterfeit, production and simulation itself ${ }^{10}$.

Baudrillard (1983) argues that a hyperreal is sheltered from the imaginary and from the distinction between the real and imaginary ( $\mathrm{p} 4$ ). He provides an example of Disneyland in USA to elaborate the difference between real and imaginary concepts (p25). Baudrillard (1983) further alerts that:

Of the same order as the impossibility of rediscovering an absolute level of the real, is the impossibility of staging an illusion. Illusion is no longer possible, because the real is no longer possible. (p 38)

\footnotetext{
${ }^{10}$ The first order of Simulacra is denoted by counterfeit what he calls 'natural law of value', the second order is labelled as that of production what he calls 'commercial law of value' and the third order is labelled as that of simulation itself what he calls 'structural law of value'. At this third level he sees that the real is hyperreal - it is only the simulated real (See Butler 1999 for a review of relevant works of Jean Baudrillard).
} 
... In this impossibility of isolating the process of simulation must be seen the whole thrust of an order that can only see and understand in terms of some reality, because it can function somewhere else...that no equivalence with the real is possible. ( $\mathrm{p} 40$ )

Hyperreality and simulation are deterrents of every principle and of every objective; they turn against power this deterrence which is so well utilised for a long time itself. ( $\mathrm{p} 43$ )

Although, Baudrillard's (1983, p 40) rather extreme statement that "no equivalence with the real is possible" may not be accurate for all aspects of our accounting practices, including the measurement of all the items of ALORE hand (see Figure 1), at least, it can provide us with a reason for socially constructing and sensitising the missing elements of the accounting equation for a just and better representation of corporate reporting.

Figure 1: ALORE hand

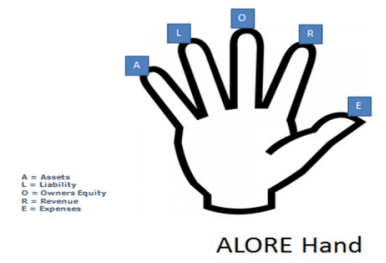

Massumi (1987) revisited the works of Jean Baudrillard, Gilles Deleuze and Félix Guattari on the concept of simulacrum in an article entitled: "Realer than real: The simulacrum according to Deluze and Guattari". Massumi also argues that Deleuze and Guattari have opened up the issue of representation with a moderately positive attitude compared to Buadrillard who has extreme views on the substitution of signs of the real for the real which no longer bear a relation to any reality whatsoever. According to Deluze and Guatarri, it appears that "the resemblance of the simulacrum is a means, not an end" (Massumi, 1987, p2). He further argues that, albeit, as the world is a complex circuit of interconnected simulations; we need to consider not only how the model and the copy or the real and the imaginary may differ but also between the modes of simulations among various layers. For example, at the standard setting level the signs are at the surface level and seen to be normative rules.

Baudrillard (1983) also warns that: "The very definition of the real becomes: that of which it is possible to give an equivalent reproduction...the real is not only what can be reproduced, but that which is always already reproduced ... that is, the hyperreal ... which is entirely in simulation. (p146) 
Similar to Jean Baurillard, we believe, some of the ALORE (if not all) items may have the characteristics of the hyperreal (economic or other realities) which can only be apprehended through 'social construction' (Hines 1988) and in simulation. For example, the fair value determination at the third tiers (Hitz 2007) for many organisations may have similar characteristics (see Bougen and Young 2012).

To reiterate, the assumption on the selection of any layer, in our case - sign and referent - will be value laden. The selection of any layer is however, we argue, centered on value based choices and views about reality. In any case, the thrust for this discourse is to sensitise the practice that creates reality from the sign layer by objective derivation of information through financial reporting using extant standards and regulations. Here, we will argue, similar to Massumi (1987), the signs are to be considered as means.

\section{Duality check using the prevalent accounting equation}

The currently accepted accounting equation assumes that information or values of all layers such as sign to referent [or any other selected layers (Mattessich 2003) of choice] are equal (as in Equation 1 below) and seen as transparent and known like the ancient Sumerian world (cf., MacIntosh et al, 2000). There are no gaps in discharging accountability to the users of financial statements and/or the greater community. Thus, the relationships of wealth among our selected two layers can be stated as follows:

$$
\text { Wealth }_{\text {sign }}=\text { Wealth }_{\text {referent }}
$$

Whereby at all layers the application of the current accounting equation will result in the same wealth determination as follows:

$$
\sum_{i=1}^{n} A_{i t}=\sum_{i=1}^{n} L_{i t}+\text { Wealth }_{t}
$$

Where: Wealth $_{t}=$ Wealth $_{t-1}+\left(\sum_{i=1}^{n} R_{i t}-\sum_{i=1}^{n} E x_{i t} \pm \sum_{i=1}^{n} N A O E_{i t}\right)$

$A_{i t}=$ Assets of $\mathrm{i}^{\text {th }}$ item at time period $\mathrm{t}$;

$L_{i t}=$ Liabilities of $\mathrm{i}^{\text {th }}$ item at time period $\mathrm{t}$;

$R_{i t}=$ Revenue (income including gains) of $\mathrm{i}^{\text {th }}$ item at time period $\mathrm{t}$;

$E x_{i t}=$ Expenses of $\mathrm{i}^{\text {th }}$ item at time period $\mathrm{t}$; 
$N A O E_{i t}=$ Net appropriations to equity of $i^{\text {th }}$ item at time period $\mathrm{t}$

Equation 1 is valid and from it we would be able to determine the economic reality (wealth) using the conventional accounting systems only if it is a static like the Sumerian world as suggested by MacIntosh et al (2000), where there exist none of the following including information asymmetry, inflation/depletion; gaps in discharging accountability and other imperfections. But, if we deviate from the assumption of the static world view whereby the information or values of sign to referent (or otherwise) for any item of ALORE hand which do not match or cannot represent realties, then the use of the accounting equation such as Equation 1 for the duality check in determining economic wealth (or otherwise) cannot be considered as absolute real. In a dynamic world, an absolute equality may not be possible between layers if compared with the sign (objective) values due to the differences of fair valuations of wealth and recognition of fair income determination and even for inappropriate considerations of organisations (firms) value creating elements as in the case of Integrated Reporting (IR) framework including accountability discharging. These differences may arise as consequences of many factors including time dimensions, lack of appropriate measurement tools, different perception of realities, nonconsiderations of firm's long-term value creating elements and accountability discharge. Thus, there is a necessity to develop an augmented accounting framework, assuming information or values created through $\operatorname{sign}(s)$ is not equal to referent if considered independently in a dynamic world in which we live in and which can ultimately capture gaps/differentials in differing space-time. Here, the question remains as to whether the output of GPFR is the result of the application of the conventional accounting equation only whereby wealth is measured by comparing the transactions based changes on past events. Also, does the GPFR meet the general objective of corporate financial reporting in displaying the entity's social and economic reality entirely?

Following Mouck (2004), Baker (2006) argues that:

The concentration of accounting standards setters on reaching a consensus about the rules can be clearly explained by the theoretical framework offered by Mouck (2004) who argues that while some financial accounting representations (e.g. monetary assets and obligations; ownership claims) may be connected with knowable facts (i.e. epistemologically objective), other financial accounting representations come into existence only through a set of rules. Thus, the rules of financial accounting are like the rules of a game. Once the rules are established, 
the representations made in accordance with the rules can be said to be "objective" with respect to the rules, even if they do not represent an underlying economic reality (p540).

The creation of signs (the information provision through corporate reporting at any given time and space) by an entity, we also argue, by following existing standards, rules and regulations (such as IFRS, GAAP, SFAS, etc.) are objective because at a given time and space the GPFR is an objective creation using the signs. As we introduce the dynamic (and/or changing) nature of our contemporary world - in a hyperreal sense - into the determination of wealth (economic or otherwise) the sign(s) may not be equivalent with any other selected layers. In our case, if compared between sign to referent; which is very much in the form of socially constructing (Hines 1988), and subjective and in simulation.

Thus, if the information provisions (values or otherwise) derived from sign to referent are not equal, then the following plausible relationships may prevail for our two selected layers:

$$
\text { Wealth }_{\text {sign }} \geq \simeq<\text { Wealth }_{\text {referent }}
$$

As the determination of economic reality or wealth and/or accountability discharge moves from sign to referent (or any other layers per se such as hyperreal) the subjectivity will be greater and stochastic. If comparison is made between layers per se it may be either greater or lower or approximately equal. The chances of the comparisons being equal may be rare unless there is an offset between the right and left sides of the accounting equation among the items in ALORE hand. Because, using Baudrillard's (1994a) words, "representation stems from the principle of the equivalence of the sign and of the real" (p6), when we move from layer to layer and compare signs (objective values) to other layers there will always be differentials. At the extreme, it may become an illusion in the end when comparisons are made from sign to referent, at least for some of the ALORE items, if not for all. Once again, Baudrillard's (1994a) argument is as follows:

When the real is no longer what it was, nostalgia assumes its meaning. There is a plethora of origin and signs of reality - a plethora of truth, of secondary objectivity, and authenticity. (pp. 6-7)

In this sense, to satisfy the existing signs in the production of GPFRs consistent with the objective of such preparations including objectivity, reliability, comparability, 
relevance and neutrality (amongst other things) can become more subjective as we move from layer to layer to determine economic wealth and an appropriate layer of accountability discharge in dynamic environments.

As well, our analogies of two layers have also historical contexts in the accounting literature. In moving from sign layer to the referent layer there is a shift of metaphors as well. Over the last few decades the metaphors of decision usefulness (e.g., Beaver 2002) and information content used in capital market research are good examples of such a shift. At the referent layer if we are to reflect the wealth (economic or social) using the metaphor of accountability then we see it has become more subjective and the differentials become greater. Studies in environmental accounting including those on an Emission Trading Scheme (ETS) are good examples of shifts from alleged to referent layers which in a sense will be more subjective if one attempts to identify the gaps among sign to referent layers for fair and just representation. Once again, in this regard we have sympathy towards the joint publication entitled 'confidence accounting: a proposal' by CISI, Long Finance and ACCA (2012); whereby it was also stated that "the use of single number for accounting terms such as profit or balance sheet value is clear and simple, but wrong" (p5). They further argue that "the use of deterministic numeric paradigm in accounting and auditing may well be the root cause of many current problems". (p6) As well, we would like to recognise the launching of the recent Integrated Reporting (IR) framework by the International Integrated Reporting Council (IIRC) for corporate reporting which aims at identifying short, medium and long term value captures of an enterprise.

As has been stated earlier, Baudrillard (1983) argues that of the same order as the impossibility of rediscovering an absolute level of real is the impossibility of staging an illusion. "Illusion is no longer possible, because the real is no longer possible." (p 38) He further argues that "ideology only corresponds to a betrayal of reality by signs; simulation corresponds to a short-circuit of reality and to its reduplication by signs. It is always the aim of ideological analysis to restore the objective process; it is always a false problem to want to restore the truth beneath the simulacrum." (p 48) And, he goes on to argue that: "In its indefinite reproduction, the system puts an end to the myth of its origin and to all the referential values it has itself secreted along the way" (p 112). Therefore, we see, at the referent layer, though not impossible, it would be difficult to get equivalence from sign to referent for some of the ALORE items and 
represent accountability discharge completely. For example, in a study on social and environmental reporting Spence (2007) argues that the production of environmental disclosures is a business case rather than the production of absolute reality. Spence (2007, p 855), in particular, argued that "both SER (social and environmental reporting) and corporate social responsibility (CSR) are driven by numerous motivations, although these motivations essentially form part of a business case". This is an indication that there exist gaps between created sign and referent in that the absolute level of representation has not been made which is dependent on ideologies being adopted. A further example, Messner (2009) argues that "a consideration of limits of accountability is crucial if we want to understand the full ethical dimension of practice of exchanging accounts" (pp. 936-937). This is indicative of gaps which will always remain between sign to any other layers depending upon the limits of accountability. Roberts (2009) argues that "accountability is thereby reconstituted as a vital social practice - an exercise of care relation to self and others, a caution to compassion in relation to both self and others, and an ongoing necessity as a social practice through which to insist upon and discover of our responsibility to and for each other" ( $p$ 969). In this sense, once again, whatever accountability discharge is created by the sign using the current standards or rules or the assumed 'social contract' legitimacy for corporate reporting there will always be gaps from sign to referent or any other layers per se for such presentations.

Buadrillard (1983) argues that "The hyperreal represents a much more advanced phase, in the sense even this contradiction between the real and the imaginary is effaced. The unreal is no longer that of dream or fantasy, of a beyond or a within, it is that of a hallucinatory resemblance of the real with itself' ( $p$ 142). He further argues that "the very definition of the real becomes: that of which it is possible to give an equivalent reproduction (p 146). That is, "the hyperreal transcends representation (cf., Lyotard, L'Art Vivant, number of hyperrealism) only because it is entirely in simulation". (Baudrillard 1983, p 147)

Baudrillard (1983) defines hyperrealism as "It is reality today that is hyperrealist" (p 147). He argues that "today it is quotidian reality in its entirety - political, social, historical and economic - that from now on incorporates the stimulatory dimension of hyperrealism" ( $p$ 147). In this sense, the influential theses of Ijiri (1986) that the impulse can be measured for some of the ALORE items which will ultimately 
improve conventional accounting practices in representing the augmented reality of wealth (or otherwise) determination. This is not to claim that it is the end of metaphysics in the era of hyperrealilty; rather, wealth at the (alleged or) referent layer (or any other selected layer) is in simulation and will have greater differentials.

\section{Augmented accounting framework (equation)}

Following on from the differential relationships among layers as discussed in the earlier section the following augmented accounting framework is derived to indicate differentials (gaps) in the conventional accounting equation:

$$
\left(\sum_{i=1}^{n} A_{i t} \pm \sum_{i=1}^{n} \lambda A_{i t}\right)-\left(\sum_{i=1}^{n} L_{i t} \pm \sum_{i=1}^{n} \lambda L_{i t}\right)>\cong<\left[\text { SignWealt } h \pm \sum_{i=1}^{n} \lambda(\text { Sign-referenjWealth }]\right. \text { (Eq. 2) }
$$

Where $\lambda$ (differentials from sign to referent values) $=$ the difference between signs [allowable measurements of resources and obligations (stochastic or otherwise)] and referent [impressions or tracing on real (absolute) wealth (values of resources and obligations) at time $t$ including accountability discharge - measurable or nonmeasurable by signs] layers.

Thus, following from the sign to referent metaphors, a claim is that the one-to-one correspondence is still possible for a taken as granted static world. That is, if all the values (or otherwise) remain stable or known for all the ALORE items with no inflation or deflation, measurable, transparent and determinant, accounting's role for the duality check using the current accounting equation is valid. Otherwise, it is the augmented accounting equation (Equation 2 above) which is indicative of the gaps with missing elements (if any), given differing epistemic choices and ontological assumptions about reality is possible. Once again, of course, this is not to claim that it is an easy solution for the identification or measurement of differentials at various layers; rather, it is an indication about the plausible gaps/differentials in representing accounting's role for duality check by the conventional (current) accounting equation for equality; if decision usefulness objectivity for the preparation of GPFR is considered. $^{11}$ To reiterate, if our general augmented framework is considered, as always, in a dynamic world and/or imperfect world, the relationships among our two layers of economic and social wealth will be as follows:

\footnotetext{
${ }^{11}$ Of course, this can only be valid if a 'Balance Sheet approach' is considered in determining an entity's real wealth.
} 


$$
\text { Wealth }_{\text {Sign }}>\cong<\text { Wealth }_{\text {referent }}
$$

If wealth at sign layer $\left(\right.$ Wealth $\left._{\text {Sign }}\right)$ is greater than wealth at the referent layer then the relationship between value sign and value referent can be either Wealth $_{\text {sign }}-u^{\prime}=$ Wealth referent (in a negative trajectory) or Wealth $_{\text {sign }}+u^{\prime}=$ Wealth referent (in a positive trajectory). Here, $u^{\prime}$ is considered to be the aggregate or cumulative differences between sign and referent value at time t. Finally, if the sign value is the same as the referent value then the relationship is Wealth $_{\text {sign }} \pm 0=$ Wealth referent; which will be a rare case given the subjectivity or randomness of the derivation of fair values of resources and obligations or determination of value-creating (otherwise) elements at the referent layer. In any case, we are assuming such a derivation, as always, is socially constructing and subjective in nature at. That is, at the referent layer the determination of the provision of information may come from different sources (academic or practitioner ${ }^{12}$ ) using differing instruments and assumptions subjectivity is the game to work towards referent realities with augmented models or frameworks.

An observation of this augmented equation is that for a given space-time the left and right sides of the equation may not be equal given the gaps on the provision of information (values or otherwise) from sign to referent, which are considered independently; it is unlikely given there is a situation of offsetting in a pair wise comparison (ie, sign and referent or vice versa). Thus, it is obvious that gaps/differentials between the right hand and left hand sides of the augmented equation can either be positive or negative or approximately equal. That is, if the accumulated sign to referent values for all resources/left-hand-side is greater than the accumulated sign to referent values of all right-hand-side for obligations or accountability discharges; then there is a positive values (financial, value-creating and/or non-financial indicators) for sign to referent for the entity for a given time and space under consideration. That is, there is an expected value or positive impression on wealth trajectory for the entity to be considered, albeit, at an augmented or stochastic level. On the other hand, if the accumulated differences from sign to

\footnotetext{
${ }^{12}$ One such example we can accept the proposal and suggestion by CISI, Long Finance and ACCA (2012); what they are calling as 'Confidence Accounting" for financial reporting and decision usefulness.
} 
referent values for all resources are less than the accumulated differences from sign to referent values of all right hand side of the augmented equation; then there is a negative value for the entity under consideration. That is, there is an expected loss or negative impression to be considered from the existing wealth.

Not only is the augmented framework applicable for sensitising the measurement and accounting for sustainability and accountability aspects, but also it can be extended for further dialects and debates on how accounting can play role in global complex financial systems and financialisation. That is, if we are to imagine ${ }^{13}$ the wealth at any level we have to take into account the changes of wealth due the economic growth or atrophy; and/or changes in fair values of assets and liabilities. Since the determination of the consequences of global financial complex systems and its impact on financialisation is considered to be problematic; understanding socio-economic rationalities including ideological issues is equally important for better representation of accountability. As we are living in a global world economy and none of us (in developed or emerging economies) can step out of its financial implications; it is important for us as accounting academics and professionals to apprehend these issues if we are to be fair in representing and imagining an entity's wealth. Entities or corporations are not isolated from the global world economy. The implication of global finance and financialisation in respect of dealing in financial markets and the juggling of capital movements between developed and emerging economies can become out of control, as has been experienced in the recent past, which ultimately can result in instability in imagining the fair values of assets and liabilities of entities.

As well, we see the augmented framework can lead us as accountants to a greater understanding of uncertainties or risks ${ }^{14}$ in imagining or making sense of wealth at the (alleged or) referent levels (if any). For example, Ben-Ami (2001) argues that risk aversion and regulation are interlinked matters. He further argues that it is possible that excessive regulation can reshape the mood of risk aversion in financial markets and the fear of which can represent "a real threat to humanity rather than the lack of

\footnotetext{
${ }^{13}$ We are using the term imagine rather than determination in a measurement sense; because the nature of valuation in accounting (or any other discipline) is subjective in nature and somewhat hyper real. Accounting for sustainability and accountability discharge through corporate reporting is subjective as well.

${ }^{14}$ Here again we are not contradicting confidence accounting with what accountants should or should not do. That is, whether the imagination or assessment of risk is in the scope of an accountants' job or not; it needs a further debate.
} 
sufficient regulation which can normally be seen as the problem". (p.1) Likewise, what we are alluding to here is that we (as accountants) should not isolate ourselves from issues that give rise to instability in wealth determination or imagination due to the dynamic nature of accountings that from time to time faces instability and crisis in complex financial systems. This, we see as having implications and ramifications for accounting disciplines including corporate reporting.

\section{Fair value context and the augmented accounting equation: a note}

Our augmented framework does have an intuitive implication for many facets of accountings including the fair value debate. In September 2007 the FASB issued SFAS (Statement of Financial Accounting Standards) No. 157 on the measurement of fair value. It specifies amongst other things the definition and hierarchy to be used in fair value measurements. The issues of reliability and relevance and their trade-off in providing information to users are the triggering factors for such a pronouncement. The relevance ground has received greater support from many corners (academic and practitioner); though there are some critics (see Laux and Leuz 2009, Ryan 2008, and Plamrose 2009) of such an implementation. Laux and Leuz (2009) argue that "the fair value debate is far from over and much remains to be done" ( $p$ 833). They argue that the fair value might not be suitable for investors and therefore it does not suit the business model of most banks if the investors hold illiquid assets to maturity. Whittington (2008) argues that "in a realistic market setting, the search for a universal measurement method may be fruitless and a more appropriate approach to the measurement problem might be how to define a clear measurement objective and to select the measurement method that best meets that objective in the particular circumstances that exist in relation to each item in the accounts". (p 139) Palmrose (2009) argues that the adaptation of fair value to reflect the economic substance may be useful for making economic decisions, but as heterogeneous users of financial statements may be dismayed at the determination of fair values in particular using the mark-to-model approach (ie, tier 3 valuations, see Hitz 2007). She also argues that marking up through the marking-to-market approach (ie, tier 2, see Hitz 2007) to determine optimistic market values can be flawed in a bull market. It might even get worse "when market prices subsequently dropped, investors' hopes and dreams - built on the margin and based on paper - evaporated into reality of despair". (p 291) She further argues that "some worry that fair value accounting runs the risk of producing 
less accurate, less relevant and less auditable financial statements". (p 291) Quoting from Silvers (2007, p 44), she states that fair value accounting "will lead to financial statements that are fundamentally less helpful in judging the operating performance of companies, and will likely encourage management and investors to think in shorter time frames than really best”. (p 291)

The SFAS 157 specifies that fair value should be based on market information rather than be entity specific. There are many cases where fair value may not be suitable rather it is based on entity specific assumptions of their management forecasts. For example, as Whittington (2008) argues, "most notably, IAS 36, Impairment of Assets, bases recoverable amount on projected cash flows", instead of the fair value. There are many examples of entity specific issues such as provisions and some revenue recognitions. The point here is that fair value excludes entity specific assumptions. Entity specific assumptions in our view are not only dependents on the measurement perspective, but also dependent on value based accountability discharges. For example, the value of a heritage asset or monument in an entity (public or otherwise) may need to reflect accountability more than a measurement of such values for a statement of financial positions for the entity.

One of the pivotal issues that we see in regards to valuation is that it is paradoxical in nature and depends on contextual underpinnings. Mattessich (2003) argues that "accounting valuation is a methodological, not an ontological problem" (pp 460-461). The question then arises as to what comes first. Whilst we are not disagreeing with Mattessich in that "every process of valuation is a social reality, derived from mental reality of having preferences" ( $p$ 460); but such a view on the valuation is a simplistic notion. In particular, what we disagree with Mattessich (2003) over is that it is the ontological status of the person(s) or body (ies) which leads the process and on which it is very much dependent on for the real measurement of economic wealth and identification for the gaps for accountability discharge. This exercise in identifying the augmented reality can come from various epistemic standpoints from a very subjective to an objective viewpoint.

It is not an underestimation to say that an enormous amount of invisibilities face accounting practices. For Chambers it was the adaptive capacity of the firm which matters in changing economic realities (Chambers 1966). Therefore, to him it is the fair value (exit price) of assets that are the financial resources available to 
management and that are the reflection of adaptive capacity at any given point in time. Chambers's ideal, though nice to think in theory, was criticised with a crux of questions of how to determine the fair value(s). ${ }^{15}$

We live in an uncertain and imperfect world as far as economic reality is concerned. Not only has there been debate over the last half century in regards to inflation accounting and the fair value adaptation (see Chambers 1966, Edward and Bells 1961, Sterling 1970b) but there has been a lack of proper guidelines/standards on how to present financial reports that are useful to a wide range of users. That is, financial reporting has not only lost credibility for economic decision usefulness purposes in recent times but also it cannot represent the highest degree of societal accountability. Hence, there are wider gaps in relation to measurement perspective as well as what is to be represented for social accountability (Chen 1975). The adoption of fair value accounting is not without criticism. Whittington (2008) argues that "critics of fair value are, in fact, offering alternative world view of financial reporting, although this view usually is not well articulated" (p140). According to Whittington (2008) again:

The alternative view is more difficult to articulate than the fair value view because it is drawn from a diverse range of constituents of the standard-setting process who are typically commenting on particular issues from a practical perspective, rather than attempting to develop a coherent model of financial statement presentation in the manner of the authors of the framework. (p 158)

Whittington (2008) further suggests that:

The fair view emphasizes the role of financial reporting in serving investors in capital markets. It seeks accounting information that has a forward-looking content, impounding future cash flows from non-entity specific markets are complete and competitive; ideally, perfect markets would be accessible. (p 160)

The Alternative View also seeks to serve investors, broadly defined, but it gives priority to existing shareholders and regards stewardship as an important and distinct function of financial reporting. It too seeks accounting information that is relevant to forecasting future cash flows, but it assumes that this will often be achieved by providing information that is useful input to investors' valuation models, rather than direct valuation of future cash flows. Such information may be

\footnotetext{
15 Use of replacement costs (deprival value - Mattessich 1995, 2003) in the absence of appropriate measures may not be suitable to represent the reality as well. An example can be taken from a practical experience of the author: during 2008 he wanted to refinance one of his loans with a bank. The bank's requirement was to obtain a valuation from the bank's recognised representative measurers. The valuations are undertaken within two week time by three representatives. The three representatives provided three different valuations for the property. The difference from the lowest to the highest was $\$ 110$ 000. Once enquired of from the highest value quote measurer, the information obtained was that the valuation was based on replacement costs. It was not an appropriate exit price either.
} 
entity specific. This approach assumes that information asymmetry and imperfect and incomplete markets are common. (p 160)

To reiterate, Hitz (2007), from a theoretical perspective, shows that an estimation of fair value in principle has three-tiers of hierarchy. First, a market- based measure is a best estimate of fair value provided there is an active liquid market for regular trading of the item (asset). If the market prices do not exhibit sufficient quality or are not available, Hitz argues that the second level of the estimation hierarchy requires considering market prices of comparable items (assets). The problem here is that in many scenarios comparable valuation depends on the imaginations or impressions depending on time and space. If this marking-to market fails to determine the fair value then as a last resort the use of an internal estimate (the use of fundamental analysis) is to be used for fair value determination. This valuation method is called marking-to-model which has also a serious problem and is dependent on the assumptions of how such knowledge can be constructed. The introduction of IFRS 13 relates to all these tiers of valuation and most recently it was mandated that public listed companies are required to disclose all the unobservable inputs used for the third tier valuation. If mainstream assumptions (Watts and Zimmerman 1990) are considered as those on which most of the Conceptual Framework was based (in our view) over the past two to three decades, then the objective of the GPFRs including objectivity, neutrality, discharging accountability to users and relevance need to be revisited. On the other hand, if alternative subjective assumptions are considered where reality is considered to be socially constructing, subjective and somewhat hyperreal (Baudrillard 1983) then we need to adopt an augmented framework. This will, at least, we believe, indicate that there will always exist gaps between expected layers and identifying those would make the prevalent accounting equation complete.

Thus, the relationships at two layers of Fair Value will be as follows:

$$
F V_{\text {Sign }}>\cong<F V_{\text {referent }}
$$

As well, what we are alluding to here is that at the sign layer the preparation of fair value determination is objective (what else could it be?) in the identification of wealth (economic or social) and it becomes subjective when we move through to a different layer (which is similar to the concept of OMR as advanced by Mattessich 1995, 2003) - sign to referent. Then, of course, we move further to the absolute reality layer or 
hyperreality layer or dreaming or illusion layer - which is like a hallucination (Baudrillard 1983).

\section{Further convincing arguments with some examples}

We argue that our augmented framework has a lot of appeal and can be used for sensitising and improving many facets of accountings including corporate reporting to identify the gaps in representing economic and social realities considering entity specific issues in deferring space and time. Nonetheless, we believe, it will minimise our confusion in the pedagogy of accounting in that there is only one equation which can be applied to contemporary corporate or entity's reporting. Let's take a few examples to extend our convincing arguments further.

For example, Clarke et al (2002) argue that "consolidated financial statements generally do not succeed in providing useful insight into overall wealth and progress of a set of related business entities (usually corporations)" (p58). In particular, they stated that:

Consolidated statements pertaining to closed groups provide financial information of questionable value. For example, the amount of the closed-group total assets and liabilities (on a consolidated basis and based on a subset of economic entity) may exceed the total assets and liabilities of the economic entity. (Clarke et al 2002, p61)

In a recent meeting (June 2013), for example, members of the Emerging Issues Task Force (EITF) of the FASB have raised an issue (Issue 12-G) in regards to the accounting for the difference between the fair value of assets and the fair value of liabilities of Consolidated Collateralized Financing (CFE) entity, as follows:

Reporting entities are often required to consolidate CFEs. Many reporting entities elect to measure all eligible financial assets and financial liabilities of CFEs at fair value. In many instances, the aggregate fair value of assets of the CFE exceeds the aggregate fair value of the CFE's beneficial interests (liabilities). (EITF update June 2013 - emphasis is in original)

This example also suggests that there will be differentials between assets and liabilities if measured at fair values. This will obviously occur for such items in ALORE hand as have been elaborated throughout in this paper.

We can take many examples to justify our arguments for the augmented framework For example, if we consider the current recognition criteria of an intangible asset (e.g., IAS 38 or AASB 138) that is internally generated; inconsistencies emerge in their classifications and rules for valuations (see for example Skinner 2008, Cheung et 
al 2008, Wyatt 2005, Bloom 2009, Dahmash et al 2009, Petkov 2011, Lightfoot 2013). In particular, let us consider paragraph 63 of AASB 138, which states that "internally generated brands, mastheads, publishing titles, customer lists and items similar in substance shall not be recognised as intangible assets" (AASB 138 2010, p29). This amendment has changed the way in which companies classify their intangibles and as a result value their assets. This change in policy has had implications for companies who have generated intangibles internally rather than acquiring them through business combination. This would give rise to differentials and inconsistencies, as always, across companies if we follow the signs.

Another plausible example for such a gap analysis is suggested by Graul and Lekeme (1976). They have dealt with gaps that may arise in representing the economic substance of deferred taxes by the government bodies. In particular, they propose that new equity categories be created in the balance sheet to show the amount of deferred tax funds provided by the government incentive policies. Therefore, they suggested that:

The accounting equation should be changed accordingly from 'Assets = Liabilities + Owners' Equity' to 'Assets = Liabilities + Government Equity Investments + Owners Equity'. This expansion of the basic accounting equation reflects the reality that government has what is in economic substance a peculiar equity interest in the firm. (p 24)

Another example, not exhaustive, yet to be considered, from a practitioner perspective, is the proposal by CISI, Long Finance and ACCA (2012). Their joint paper "Confidence Accounting: a Proposal" provides good examples. In appendices they provide two worked examples for financial reporting reform based on hypothetical institutions: a UK-based major bank and a small professional services company.

In the letter from the researched bank's finance director to the board on the occasion of the first set of accounts prepared using the so-called "confidence accounting" by CISI, Long Finance and ACCA (2012, p 29) states the following:

This paper presents Banco-UK's (hypothetical bank) accounts using the new Confidence Accounting format, promoted by various regulatory and accounting bodies. Confidence accounting is an attempt to reflect the fundamental uncertainty around particular values for assets, liabilities, revenues and costs. ...

Current accounting practice and standards are based on a rarely questioned assumption: that there is single correct number for every asset value, liability 
value, element of income, etc. Any uncertainty over those values is ultimately ignored in the financial statements, despite the many, often intense, debates over what is the 'right value' that take place in many companies before the accounts are finalised and published...

They further stated that:

It is important that confidence accounting, and the estimation of measurement error in general, deals with known unknowns: the impact of known sources of uncertainty on values of asset, liabilities, income and expense. Company disclosures can and should also deal with an assessment of the unknown, in discussion about future plans, events, the economic environment, risk levels, etc., but confidence accounting does not address those aspects of disclosure(s)...

A second important note is that current accounting standards do not completely ignore uncertainty for financial institutions. Of particular note is the attempt in FAS 157 and IFRS 7 to provide favourable and unfavourable sensitivities for the values of derivative financial instruments... (p30)

In fact, this joint paper (CISI, Long Finance and ACCA 2012) shows that if the framework of confidence accounting is used for financial reporting there are many issues to be noted and in need of further research and development. For example, they noted, "many items in today's banking accounts are at extreme values and not at expected values". Using Confidence Accounting may be a way out for a better framework for disclosing such values. They argue that "Confidence Accounting is concerned with the historic uncertainty", instead of risk management. The latter, they argue, should present management's view about the future valuation. They reaffirm that "Confidence Accounting proposals are not intended to turn accountants into risk managers, but the proposals would move accountants and risk managers to work more closely together and share views, particularly on the range of balance sheet valuations" (p22). ${ }^{16}$

Likewise, we believe, for many facets of accountings including fair value disclosures, social and environmental and sustainability disclosures for greater accountability and stewardships in corporate reporting there is a need to identify the gaps (differentials) depending on the layers of comparisons (i.e., sign to referent). In other words, our imagination and theoretical development may have future appeals for regulators, educators and professionals in financial accounting and corporate reporting in that

\footnotetext{
${ }^{16}$ At the time of writing this paper, the authors of the joint paper (CISI, Long Finance and ACCA 2012) have invited comments on how financial accounts can better recognise both uncertainty and confidence about valuation. In particular, they have invited for three series of questions (see CISI, Long Finance and ACCA 2012, pp23-25) to stimulate discussion on confidence accounting and its implications on financial reporting. We could not gather together the outcome of such responses at this stage.
} 
there is a necessity for a better conceptual framework in order to restore the credibility of accounting profession and auditors in handling the dynamic nature of accounting events including fair value determinations, decision usefulness and disclosures on corporate social responsibilities and indications on entity's wealth. In this sense the recent initiative for the integrated reporting (IR) framework considered to be a potential way forward if we are to provide a credible short-, mid- and long-term visions of an entity's impressions on wealth trajectories as has been suggested through our augmented framework.

We have shown throughout in this paper that the use of conventional accounting for corporate reporting in determining absolute wealth (at the referent level) is inadequate because today's corporate reporting is limited on the provision of information for both accountability and relevance grounds. Not only public and private sector entities do need to provide strategic information on wealth; but also they need to be more accountable and socially responsible to its stakeholders. If corporate (financial or otherwise) reporting is to provide more credible quality information in determining entity's wealth along with the provision of information for sustainability, accountability and stewardship; there is a necessity for 'integrated thinking' (IRC 2013). To us, therefore, Integrated Reporting (IR) ${ }^{17}$ initiative by the International Integrated reporting Council (IIRC) and their recent IR framework (IIRC 2013) could be considered as a potential turning point in developing differing forms of corporate reporting norms including integrating information for 'financial', 'manufactured', 'intellectual', 'human', 'social and relationship' and 'natural' capitals (IIRC 2013). This is what we see as an augmentation towards providing relevant information on entity's wealth trajectories through better corporate reporting; which is considered to be subjective, 'socially constructed' (Hines 1988) and constructing.

\section{Conclusion}

This paper is an attempt to assess the duality check of wealth determination through corporate reporting using the currently accepted accounting equation and/or conventional accounting. In a dynamic environment it is suggested that there is a need

\footnotetext{
${ }^{17}$ It should be mentioned that although there are evidences on the usage of integrated reporting by many companies over the last decades or so, but it was in August 2010 when International Integrated Reporting Committee (IIRC) first time officially launched such a framework in order "to create a globally accepted framework for accounting for sustainability” (Eccles and Armbrester 2011).
} 
for an augmented framework for better representation of economic and social realities through corporate reporting. For sensitising such an argument we have extended the prevalent accounting equation with an augmented framework using two metaphors sign to referent. We conclude from our discussion that current standards are considered to be signs and have epistemic objectivity. That is, the determination of wealth (in accounting) based on the current signs is, as always, objective. Whilst any different layer is considered other than the sign layer and if a comparison is made pairwise, there will always be differentials/gaps in determining absolute wealth (economic or otherwise) for an entity using signs that exist at any time and space and, therefore, there is a need to adopt an augmented framework. Therefore, we see accounting as socially constructed and constructing; and there needs to be an ongoing discourse which should have dialectical force for change. Moreover, not only is the augmented framework applicable for the measurement perspective; it is also applicable for ideological debate on accountability and sustainability of how we see the improvement of a greater humanity and justice across the world economies. Thus, in conclusion, considering the research efforts (normative or otherwise) over the last century including the prescriptive theories (viz., CCA, CoCoA, DVA and FVA) as have been advanced in accounting, the wealth determination not only is considered to be subjective concept in a neoliberal economic sense, it is, to reiterate, socially constructed and constructing in our dynamic world that we live in. As always, it requires augmentation(s) with value based epistemic considerations.

\section{References:}

Baker, C. R. (2006), 'Epistemological objectivity in financial reporting: Does internet accounting require a new accounting model?', Accounting, Auditing \& Accountability Journal, Vol. 19, No. 5, pp 663-680.

Baudrillard, J. (1983), Simulations, Columbia University, NY, USA

Baudrillard, J. (1994a), Simulacra and simulation, Arbour, MI: University of Michigan Press

Baudrillard, J. (1994b), The illusion of the end, Cambridge: Polity Press

Beaver, W. H. (1991), 'Problems and paradoxes in the financial reporting of future events', Accounting Horizons, Vol. 5, No. 4, December, pp 122-134.

Beaver, W. H. (2002), 'Perspective on recent capital market research', The Accounting Review, Vol. 77, Issue 2, pp 453-474

Beaver, W. H., and J. S. Demski, (1979), 'The nature of income measurement', The Accounting Review, Vol. 54, No. 1, January, pp 38-46. 
Bexter, W. T. (1975), 'Accounting values and inflation', McGraw-Hill, London.

Ben-Ami, D. (2001), Cowardly capitalism: The myth of the global financial casino, Willy and Sons, NY.

Bloom, M., (2009), 'Accounting for goodwill', ABACUS, Vol. 45, Issue 3, pp 379389.

Bougen, P. H,., and J. J. Young, (2012) 'Fair value accounting: Simulacra and simulation', Critical Perspectives on Accounting, Vol. 23, Issue 4-5, pp 390-402.

Butler, R. (1999), Jean Baudrillard: The defence of the Real, London: Sage Publications.

Chambers, R. J. (1965), 'Measurement in accounting', Journal of Accounting Research, Vol. 3 No1 Spring, pp 32-62

Chambers, R. J. (1966), Accounting, evaluation and economic behaviour, Prentice Hall, Englewood Cliffs, New Jersey.

Chatfield, M. (1974), A history of accounting thought, Hinsdale, IL: The Dryden Press

Chen, R. S. (1975), 'Social and financial stewardship', The Accounting Review, Vol.50, No 3. pp 533-543.

Cheung, E., E Evans and S. Wright (2008), 'The adoption of IFRS in Australia: The case of AASB 138 (IAS38) intangible assets', Australian Accounting Review, Vol 18, Issue $3 \mathrm{xxx}$

CISI (Chartered Institute for Securities and Investment), Long Finance, ACCA (Association of Chartered Certified Accountants), (2012), 'Confidence accounting: a proposal', UK (web access on www.accaglobal.com/content/dam/acca/global/.../tech-af-cap.pdf )

Clarke, F., and G. Dean (2007), Indecent disclosure: Gilding the corporate lily, Cambridge: U.K.: Cambridge University Press.

Clarke, F., G. Dean, E. Houghton (2002), 'Revitalising group accounting: Improving accountability', Australian Accounting Review, Vol. 12, No. 3, pp 58-72.

Cooper, D. J. (1983), 'Tidiness, muddle and things: commonalities and divergences in two approaches in management accounting research', Accounting, Organizations and Society, Vol 8, pp 269-286.

Dahmash, F. N., R, B. Durand, and J. Watson (2009), 'The value relevance and reliability of reported goodwill and identifiable intangible assets', British Accounting Review, Vol 41, no 2, pp120-137

Eccles, R. G., and K. Armbrester, (2011), 'Two disruptive ideas combined; Integrated Reporting in the cloud', IESEinsight, Issue 8, pp13-20

Edwards, E., and P. Bell, (1961), The theory and measurement of business income, Berkley University of California Press.

EITF update (2013), June 2013 meeting highlights, access on http://www.ey.com/Publication/vwLUAssetsAL/EITFUpdate_BB2560_12June20 13/\%24FILE/EITFUpdate_BB2560_12June2013.pdf 
Financial Reporting Handbook (2009), Chartered Accountants Financial reporting handbook: Incorporating all the standards as at 1 January 2009, John Wiley \& Sons, Milton, Queensland, Australia.

Foucault, M. (1977) - 'The order of things: The archaeology of the human sciences', taylor and Francis.

Gibbins, M., and R. J. Willet, (1997), 'New light on accrual aggregation and allocation, using an axiomatic analysis of accounting numbers', fundamental and statistical character', ABACUS, Vol. 33, No.2, September, pp 137-167.

Graul, P. R., and K. W. Lekeme (1976), 'On the economic substance of deferred taxes', ABACUS, Vol. 12, Issue 1, pp 14-33

Hatfield, H. R. (1930), Accounting, its principles and problems, Appleton.

Hines, R. D. (1988), 'Financial accounting: In communicating reality, we construct reality', Accounting, Organizations and Society, Vol. 13, no. 3, pp 251-261.

Hitz, J. M. (2007), The decision usefulness of fair value accounting: A theoretical perspective', European Accounting Review, Vol. 16, Issue 2, pp 323 - 362

Ijiri, Y (1986), “A Framework for triple-entry bookkeeping”, The Accounting Review, Vol. LXI, No. 4. October, pp 745-759.

Ijiri, Y (1989), Momentum accounting and triple-entry bookkeeping: Exploring the dynamic structure of accounting measurements, Sarasota: American Accounting Association.

Ijiri, Y. (1972), 'Measurement in current accounting practice: a reply', The Accounting Review, Vol. 47, pp 510-526.

International Integrated Reporting Council (IIRC) (2013), The International Integrated Reporting Framework, Dec.

Laughlin, R. (1995), 'Methodological themes - Empirical research in accounting; alternative approaches and a case for 'middle-range' thinking', Accounting, Auditing and Accountability Journal, Vol. 8, No. 1, pp 63-87.

Laux, C., and C. Leuz (2009), "The crisis of fair-value accounting: making sense of the recent debate", Accounting, Organizations and Society, Vol 34, pp 826-834.

Lightfoot, S (2013), 'Research into the accounting for intangible assets, Charter, Vol 84, No 1, pp44-45

Littleton, A. C. (1933), Accounting evolution to 1900, New York: American Institute Publishing Co.

Littleton, A. C. (1968), 'The antecedents of double-entry bookkeeping', in M. Chatfield, Contemporary studies in evolution of accounting thought, pp 21-29, Belmont, CA: Dickenson Publishing Company.

Littleton, A. C. and B. S. Yamey, (1956), Studies in the history of accounting, Homewood, IL: Richard D. Irwin, Inc.

Macintosh, N. B., T Shearer, D. B. Thornton and M Welker (2000), 'Accounting as simulacrum and hyperreality: perspectives on income and capital', Accounting, Organizations and Society, Vol. 25, pp 13-50 
Massumi, B. (1987), 'Realer than the real: The simulacrum according to Deluze and Gattori", $\mathrm{xx}$

Mattessich, R (1989), 'Accounting and the input-output principle in the prehistoric and ancient world', ABACUS, pp.74-84

Mattessich, R (1995), Critique of accounting: Examination of the foundations and normative structure of an applied discipline, Westport, CT and London: Quorum Books

Mattessich, R, (1987), 'Prehistoric accounting and the problems of representation: an archaeological evidence of the Middle East from 8000 BC to 3000 BC', Accounting Historians Journal, pp 71-91

Mattessich, R. (1964), Accounting and Analytical Methods, Irwin.

Mattessich, R. (2003), 'Accounting representation and onion model of reality: a comparison with Baudrillard's orders of simulacra and his hyperreality', Accounting,Organizations and Society, Vol. 28, pp 443-470.

Messner, M. (2009), 'The limits of accountability', Accounting, Organizations and Society, Vol 34, pp 918-938

Mathews, R. L. (1965), 'Price-level changes and useful information', Journal of Accounting Research, Spring, pp. 133-155.

Miller, P., and C. Napier (1993), 'Genealogies of calculation', Accounting, Organizations and Society, Vol. 18 (7/8), pp 631-647

Mouck, T. (2004), 'Institutional reality, financial reporting and the rules of the game', Accounting, Organizations and Society, Vo. 29, pp 525-541

Pacioli, L. (1494), Summa de arithmetica, geometria, proportioni et proportionalita (Paganino de Paganini, Venice, 1494). Translated by R. G. Brown and K. S. Johnston, Pacioli on Accounting, McGraw-Hill 1963

Patton, W. A. and A. C. Littleton (1940), 'Monograph No 3: An introduction to corporate accounting standards', American Accounting Association

Petkov, R., (2011), 'Initial identification of internally generated intangibles assets in the context of the definitions of an asset and an intangible asset', Journal of Theoretical Accounting Research, vol 6. Pp1-9

Plamrose, Z, V. (2009), 'Science, politics, and accounting: A view from the potomac', The Accounting Review, Vol.84, No 2, pp 281-297.

Ravenscroft, S., and P. F. Williams (2009), 'Making imaginary worlds real: The case of expensing employee stock options', Accounting, Organizations and Society, 34: pp 770-786.

Roberts, J. (2009), 'No one is perfect: the limits of transparency and an ethic for 'intelligent' accountability', Accounting, Organizations and Society, Vol 34., pp 957-970.

Rosenfield, P. (1975), 'CPP accounting relevance and interpretability', Journal of Accountancy, August, pp. 52 -59.

Ryan, S. G., (2008), 'Accounting in and for the Subprime Crisis', The Accounting Review, Vol. 83, No 6, pp 1605-1638. 
Salvary, S. C. (1989), An analytical framework for accounting theory, McQueen Accounting Monograph Series, Vol.5, Fayetteville: University of Arkansas.

Saussure, F (1959), Courses in general linguistics, New York: McGraw- Hill

Searle, J. R. (1995), The construction of social reality, New York: The Free Press.

Silvers, D. A. (2007), 'The current state of auditing profession: A view from workerowners', Accounting Horizons, 21 (dec), pp 437-444 xx

Skinner, D. J. (2008), 'Accounting for intangibles: A critical review of policy recommendations', Accounting and Business Research, Vol 38, No 3, pp191-204

Spence, C., (2007), 'Social and environmental reporting and hegemonic discourse', Accounting, Auditing and Accountability Journal, Vol. 20. No. 6.,pp 855-882.

Sprague, C. E. (1880), 'The algebra of accounts', Series of articles in The Bookkeeper (New York), July and August.

Statement of Financial Accounting Standards (SFAS), FASB, USA

Sterling, R. R. (1970a), Theory of measurement of enterprise income, The University Press Kansas.

Sterling, R. R. (1970b), 'On theory construction and verification', The Accounting Review, Vol. 45, pp 444-457.

Sweeny, H. W. (1936), Stabilized accounting, Harper Brothers

Vickrey, D. W., (1970), 'Is accounting a measurement discipline?', The Accounting Review, Vol. 53, No. 3, October, pp731-42.

Watts, R. L. and J. L. Zimmerman (1990), 'Postive accounting theory: a ten years perspective', The Accounting Review, Vol. 65, No 1, pp 131-156.

Whittington, G. (2008), 'Fair value and the IASB/FASB conceptual framework project: an alternative view', ABACUS, Vol. 44, Issue 2, pp 139-168

Willett, R., (1987), 'An axiomatic theory of accounting measurement', Accounting and Business Research, No. 66, spring, pp 155-171.

Willett, R., (1988), 'An axiomatic theory of accounting measurement -part II', Accounting and Business Research, No.73, Winter, pp 79-91.

Wyatt, A (2005), 'Accounting recognition of intangible assets: Theory and evidence of economic determinants' The Accounting Review, Vol. 80, No. 3, pp 967-1003. 